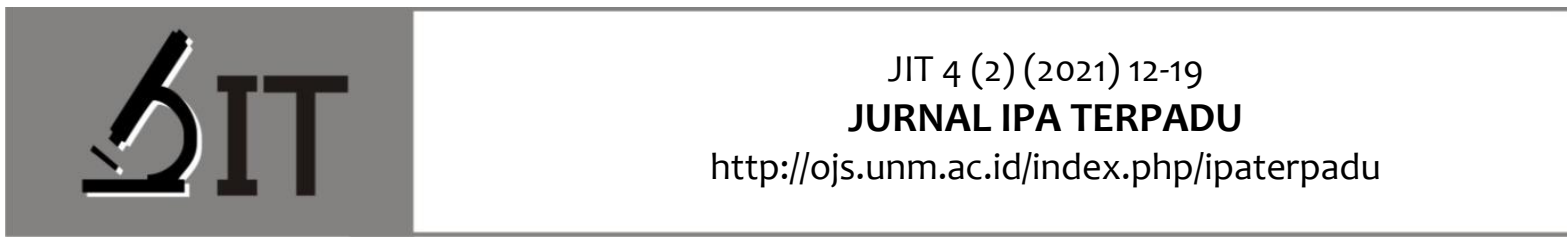

p-ISSN : 2597-8977

e-ISSN : 2597-8985

A Husnul Haerana*) Prodi Pendidikan IPA FMIPA Universitas Negeri Makassar

Ramlawat Prodi Pendidikan IPA FMIPA Universitas Negeri Makassar

Sitti Rahma Yunus Prodi Pendidikan IPA FMIPA Universitas Negeri Makassar

*) Correspondence Author: Ranahaerana97@gmail.com

\section{PENGARUH MEDIA SIMULASI PhET TERHADAP HASIL BELAJAR IPA PESERTA DIDIK KELAS IX SMPN 13 MAKASSAR (STUDI PADA MATERI POKOK LISTRIK DINAMIS)}

Abstrak: Penelitian ini bertujuan untuk mengetahui : (1) peningkatan hasil belajar peserta didik kelas IX SMPN 13 Makassar yang diajar menggunakan media simulasi PhET dan yang menggunakan media gambar, (2) pengaruh media simulasi PhET terhadap peningkatan hasil belajar peserta didik kelas IX SMP Negeri 13 Makassar. Penelitian ini merupakan Quasi Experimental dengan menggunakan desain Nonequivalent Control Group Design. Populasi penelitian adalah seluruh peserta didik kelas IX SMP Negeri 13 Makassar. Pengambilan sampel melalui teknik Purposive Sampling dan diperoleh kelas IX 1 sebagai kelas eksperimen dan IX 2 sebagai kelas kontrol. Instrumen penelitian berupa tes hasil belajar dalam bentuk pilihan ganda berjumlah 30 item soal dengan memberikan pretest dan posttest. Analisis data dilakukan dengan menggunakan analisis deskriptif dan inferensial. Statistik deskriptif untuk mengetahui hasil statistik pada skor rata-rata hasil belajar. Hasil analisis deskriptif hasil belajar peserta didik pada kelas eksperimen diperoleh skor rata-rata $\mathrm{N}$-Gain 0,72 berada pada kategori tinggi dan pada kelas kontrol yaitu 0,53 berada pada kategori sedang. Hasil analisis inferensial diperoleh dengan menggunakan uji-t (uji hipotesis) menunjukkan bahwa Ho ditolak dan $\mathrm{H} 1$ diterima, sehingga dapat disimpulkan bahwa media simulasi PhET berpengaruh terhadap peningkatan hasil belajar peserta didik kelas IX SMP Negeri 13 Makassar pada materi listrik dinamis.

Kata Kunci: Media Simulasi PhET, hasil belajar.

Abstract: This study aims to find out: (1) The increase of students learning outcomes by using PhET simulation media, and by using image media, (2) The effect of PhET Simulation Media on Students learning outcomes. This research is Quasi-Experimental using Nonequivalent Control Group Design. The population of this study was all Students Grade IX SMPN 13 Makassar. Sampling through Purposive Sampling technique and obtained grade 9.1 as the experimental grade and 9.2 as the Control grade. The instrument of learning outcomes in the form of multiple choices totaling 30 items. Data analysis was performed using descriptive and inferential analysis. Descriptive statistics to find out statistical results on average learning outcomes. The results of the descriptive analysis of the learning outcomes of the students in the experimental grade were obtained the average score of $\mathrm{N}$-Gain 0.72 is in the high category and the control grade is 0.53 in the moderate category. The inferential analysis results obtained by using the t-test (hypothesis test) indicate that $\mathrm{Ho}$ is rejected and $\mathrm{H} 1$ is accepted, so it can be concluded that the PhET simulation media affect the increase on Students learning outcomes Grade IX SMPN 13 Makassar in the subject matter of dynamic electricity.

Keyword: PhET Simulation Media, learning outcomes. 


\section{PENDAHULUAN}

Teknologi Informasi dan Komunikasi digunakan sebagai media pembelajaran dalam proses belajar mengajar. Salah satu media pembelajaran berbasis Teknologi Informasi dan Komunikasi yaitu PhET (Physics Education Technology). PhET merupakan media simulasi berbasis audiovisual dimana guru dapat menyajikan beberapa video simulasi dalam pembelajaran IImu Pengetahuan Alam (IPA).

Salah satu media pembelajaran inovatif yang kini banyak digunakan adalah media simulasi PhET. Media ini dikembangkan oleh tim dari Universitas Colorado Amerika Serikat yang diketuai oleh Carl Wieman. Software simulasi interaktif ini dibuat untuk membantu peserta didik memvisualisasikan konsep secara utuh dan jelas. Simulasi PhET menghidupkan apa yang tidak terlihat oleh mata melalui penggunaan grafis dan kontrol intuitif seperti klik dan tarik manipulasi, slider dan tombol radio. Selain mudah digunakan dan diaplikasikan di dalam kelas, PhET juga bisa digunakan secara online di situs https://PhET.colorado.edu. PhET membutuhkan komputer yang sudah terinstal program Java dan/atau Flash (Sumargo, Yuanita, \& Lenny, 2014).

Aplikasi ini memiliki animasi interaktif dikembangkan seperti permainan yang dapat memungkinkan siswa bereksplorasi. Selain itu PhET juga menekankan hubungan antara fenomena kehidupan nyata dan ilmu yang mendasarinya yang diungkapkan dalam model visual dan konseptual dengan pendekatan berbasis penelitian yang mendukung keterlibatan siswa sehingga membantu mereka untuk memahami konsep fisika. Courseware semacam ini didesain untuk menggantikan kegiatan praktikum dimana siswa melakukan percobaan secara virtual di depan komputer. Dalam paket simulasi PhET terdapat lebih dari 80 judul praktikum. Pada tahun 2010 simulasi ini telah digunakan oleh 10 juta orang di berbagai Negara. Pada awalnya, PhET dibuat untuk proses belajar mengajar fisika, namun dalam perkembangannya simulasi PhET juga disediakan untuk pengajaran Kimia, Biologi, Matematika, dan ilmu lainnya (Wieman, Adams, \& Perkins, 2009).

Berdasarkan observasi yang dilakukan di salah satu SMP di Makassar yaitu di SMPN 13 Makassar banyak peserta didik yang mengganggap bahwa mata pelajaran IPA termasuk mata pelajaran yang sulit. Berdasarkan hasil wawancara dengan peserta didik, pembelajaran IPA mengandung banyak prinsip, konsep, dan teori yang abstrak sehingga sulit untuk dipahami. Mereka kesulitan untuk menghubungkan konsep-konsep yang terkait. Berbagai kesulitan yang dihadapi peserta didik mengakibatkan siswa kurang antusias dalam mengikuti proses pembelajaran dan kesulitan jika diberi tugas mandiri.

Simulasi PhET adalah media pembelajaran interaktif yang memberi kesempatan bagi siswa untuk mempelajari materi setiap saat, dapat diulang-ulang sampai memahami konsep, memandu, dan menggugah untuk mengalami proses belajar secara mandiri, memahami gejala alam melalui kegiatan ilmiah, dan meniru cara kerja ilmuan dalam menemukan fakta, konsep, hukum atau prinsip-prinsip fisika yang bersifat invisible. Simulasi yang disediakan oleh PhET sangat interaktif yang mengajak peserta didik untuk belajar dengan mengeksplorasi secara langsung. simulasi PhET menciptakan sebuah animasi dari fakta yang abstrak atau fenomena seperti atom, elektron, foton, dan medan magnet. Simulasi PhET menyediakan serangkaian alat dan bahan yang akan digunakan dalam kegiatan eksperimen. Selain itu, penggunaan simulasi PhET dapat membuat pembelajaran menjadi suatu proses penemuan yang merupakan ciri dalam pembelajaran fisika (Wartono, 2003).

Menurut penelitian yang dilakukan oleh Wibowo (2018) bahwa Media PhET dapat memberi pengaruh terhadap pengusaan konsep karena media PhET menghidupkan yang kasat mata melalui penggunaan grafis. Simulasi seperti ini menjadikan hal-hal yang abstrak tentang sifat- sifat cahaya akan digambar melalui grafis sehingga siswa tidak hanya membayangkan, tapi bisa melihat langsung peristiwa fisis yang terjadi.

Materi yang dipilih pada penelitian ini yaitu materi Listrik Dinamis disebabkan karena materi listrik dinamis ini merupakan materi yang memiliki konsep yang abstrak dan memiliki perhitungan. Namun, media simulasi PhET dapat menampilkan peristiwa yang sering peserta didik alami ke dalam 
bentuk animasi bersama dengan perhitungannya. Media ini dapat membuat peserta didik lebih cepat memahami dan menemukan konsep. Simulasi komputer selain mampu menyederhanakan suatu hukum atau teori, juga mampu merubah pandangan siswa terhadap mata pelajaran IPA yang awalnya sulit menjadi menarik dan mudah dimengerti.

Berdasarkan uraian di atas, maka tujuan penelitian ini sebagai berikut:

1. Untuk mengetahui peningkatan hasil belajar peserta didik kelas IX SMP Negeri 13 Makassar yang diajar dengan menggunakan media simulasi PhET pada materi pokok listrik dinamis.

2. Untuk mengetahui peningkatan hasil belajar peserta didik kelas IX SMP Negeri 13 Makassar yang diajar dengan menggunakan media gambar pada materi pokok listrik dinamis.

3. Untuk mengetahui ada tidaknya pengaruh media simulasi PhET terhadap peningkatan hasil belajar peserta didik kelas IX SMPN 13 Makassar pada materi pokok listrik dinamis.

\section{METODE}

Jenis penelitian yang digunakan adalah eksperimen semu (quasi eksperiment) dengan desain penelitian nonequivalent control group design. Penelitian dilaksanakan pada Semester Ganjil Tahun Ajaran 2019/2020 di SMP Negeri 13 Makassar.

Pengambilan sampel dilakukan dengan teknik purposive sampling, atas dasar pengelompokkan kelas yang bersifat homogen. Populasi dalam penelitian ini adalah seluruh peserta didik kelas IX SMP Negeri 13 Makassar dengan jumlah total peserta didik sebanyak 360 orang. Adapun sampel penelitiannya adalah kelas IX 1 sebagai kelas eksperimen dengan jumlah peserta didik sebanyak 36 orang dan kelas IX 2 sebagai kelas kontrol dengan jumlah peserta didik sebanyak 36 orang. Variabel yang diselidiki dalam penelitian ini adalah media simulasi PhET dengan hasil belajar.

Data hasil belajar peserta didik diperoleh melalui pemberian tes hasil belajar berupa tes tertulis pretest (sebelum diberikan perlakuan) dan posttest dalam bentuk pilihan ganda sebanyak 30 item. Data yang diperoleh dari sampel penelitian ini berupa data kuantitatif skor hasil belajar peserta didik yang kemudian diolah dengan statistik deskriptif dan statistik inferensial. Statistik deskriptif berfungsi untuk mendeskripsikan objek yang diteliti melalui data sampel. Analisis ini bertujuan untuk mendeskripsikan peningkatan hasil belajar peserta didik untuk kelas eksperimen dan kelas kontrol. Sedangkan statistik inferensial digunakan untuk melakukan generalisasi dari sampel ke populasi

\section{HASIL DAN PEMBAHASAN}

\section{Hasil}

\section{a. Analisis Statistik Deskriptif}

Hasil analisis statistik deskriptif menunjukkan deskripsi tentang karakteristik distribusi nilai tes hasil belajar dari masing-masing kelompok penelitian. 
Tabel 1. Hasil Analisis Statistik Deskriptif Data Hasil Belajar Kelas Eksperimen dan Kelas Kontrol

\begin{tabular}{|c|c|c|c|c|c|}
\hline \multirow{2}{*}{ No. } & \multirow{2}{*}{ Statistik } & \multicolumn{2}{|c|}{ Kelas Eksperimen } & \multicolumn{2}{|c|}{ Kelas Kontrol } \\
\hline & & Pretest & Posttest & Pretest & Posttest \\
\hline 1. & Jumlah Sampel & 36 & 36 & 36 & 36 \\
\hline 2. & Skor Tertinggi & 14 & 28 & 15 & 26 \\
\hline 3. & Skor Terendah & 6 & 20 & 6 & 11 \\
\hline 4. & Skor Rata-rata & 10,36 & 24,50 & 10,05 & 20,72 \\
\hline 5. & Std. Deviasi & 1,89 & 2,34 & 2,20 & 4,00 \\
\hline 6. & Varians & 3,60 & 5,51 & 4,85 & 16,03 \\
\hline
\end{tabular}

Berdasarkan Tabel 1 di atas, rangkuman hasil Analisis statistik deskriptif data yaitu hasil pretest hasil belajar IPA pada kelas eksperimen yang merupakan kelas yang diberikan perlakuan, diperoleh skor rata-rata peserta didik 10,36 dengan standar deviasi 1,89. Skor tertinggi yang diperoleh 14 dan skor terendah 6 dengan skor ideal tertinggi yaitu 30. Hasil posttest hasil belajar IPA pada kelas eksperimen, diperoleh skor rata-rata peserta didik 24,50 dengan standar deviasi 2,34. Skor tertinggi yang diperoleh 28 dan skor terendah 20 dengan skor total tertinggi yaitu 30.

Hasil pretest hasil belajar IPA pada kelas kontrol, diperoleh skor rata-rata peserta didik 10,05 dengan standar deviasi 2,20. Skor tertinggi yang diperoleh 15 dan skor terendah 6 dengan skor total tertinggi yaitu 30. Hasil posttest hasil belajar IPA pada kelas kontrol, diperoleh skor rata-rata peserta didik 20,72 dengan standar deviasi 4,00. Skor tertinggi yang diperoleh 26 dan skor terendah 11 dengan skor ideal yaitu 30 .

Tabel 2. Rata-rata skor N-Gain Tes Hasil Belajar Kelas Kelas Eksperimen dan Kelas Kontrol

\begin{tabular}{lcccc}
\hline \multirow{2}{*}{ Kelas } & \multicolumn{2}{c}{ Skor } & \multirow{2}{*}{ Rata-Rata Skor N-Gain } & Kategori \\
\cline { 2 - 3 } & Pre-Test & Post-Test & & \\
\hline Kelas Eksperimen & 10,36 & 24,50 & 0.72 & Tinggi \\
Kelas Kontrol & 10,05 & 20,72 & 0.53 & Sedang \\
\hline
\end{tabular}

Tabel 2 menunjukkan bahwa skor $\mathrm{N}$-gain hasil belajar peserta didik kategori kelas eksperimen termasuk dalam kategori tinggi dengan skor N-Gain 0,72. Sedangkan, skor N-gain hasil belajar peserta didik pada kelas kontrol termasuk dalam kategori sedang dengan skor N-Gain 0,53.

Tabel 3. Peningkatan Tiap Indikator Hasil Belajar Kelas Eksperimen dan Kelas Kontrol

\begin{tabular}{|c|c|c|c|c|c|c|c|c|c|c|}
\hline \multirow[b]{2}{*}{ No } & \multirow[b]{2}{*}{ Indikator } & \multirow{2}{*}{$\begin{array}{l}\text { Juml } \\
\text { ah } \\
\text { soal }\end{array}$} & \multicolumn{2}{|c|}{ Pretest } & \multicolumn{2}{|c|}{ Posttest } & \multicolumn{2}{|c|}{ Eksperimen } & \multicolumn{2}{|c|}{ Kontrol } \\
\hline & & & $E$ & $\mathrm{~K}$ & $E$ & K & $\mathrm{N}$-Gain & $\begin{array}{c}\text { Katego } \\
\text { ri }\end{array}$ & N-Gain & Kategori \\
\hline 1. & $\begin{array}{l}\text { Menuliskan syarat } \\
\text { terjadinya arus listrik }\end{array}$ & 3 & 39 & 38 & 83 & $\begin{array}{l}6 \\
4\end{array}$ & 0.64 & Sedang & 0.37 & Sedang \\
\hline 2. & $\begin{array}{l}\text { Menghitung besar } \\
\text { arus listrik }\end{array}$ & 3 & 33 & 43 & 104 & 95 & 0.95 & Tinggi & 0.80 & Tinggi \\
\hline 3. & $\begin{array}{l}\text { Menjelaskan } \\
\text { karakteristik } \\
\text { rangkaian listrik seri } \\
\text { dan paralel }\end{array}$ & 3 & 37 & 32 & 90 & 77 & 0.75 & Tinggi & 0.59 & Sedang \\
\hline 4. & $\begin{array}{l}\text { Menghitung besar } \\
\text { hambatan total pada } \\
\text { rangkaian listrik seri, }\end{array}$ & 3 & 34 & 38 & 60 & $\begin{array}{l}6 \\
6\end{array}$ & 0.35 & Sedang & 0.40 & Sedang \\
\hline
\end{tabular}




\begin{tabular}{|c|c|c|c|c|c|c|c|c|c|c|}
\hline & $\begin{array}{ll}\text { paralel } & \text { dan } \\
\text { rangkaian campuran }\end{array}$ & & & & & & & & & \\
\hline 5. & $\begin{array}{l}\text { Menuliskan konsep } \\
\text { hukum ohm }\end{array}$ & 3 & 33 & 33 & 103 & $\begin{array}{l}8 \\
9\end{array}$ & 0.93 & Tinggi & 0.75 & Tinggi \\
\hline 6. & $\begin{array}{l}\text { Mendeskripsikan } \\
\text { bunyi hukum I } \\
\text { Kirchhoff }\end{array}$ & 2 & 21 & 27 & 46 & 35 & 0.49 & Sedang & 0.18 & Rendah \\
\hline 7. & $\begin{array}{l}\text { Menerapkan konsep } \\
\text { hukum I Kirchhoff }\end{array}$ & 2 & 26 & 22 & 60 & 61 & 0.74 & Tinggi & 0.78 & Tinggi \\
\hline 8. & $\begin{array}{l}\text { Menjelaskan } \\
\text { berbagai sumber } \\
\text { energi listrik }\end{array}$ & 3 & 34 & 27 & 83 & 45 & 0.66 & Sedang & 0.22 & Rendah \\
\hline 9. & $\begin{array}{l}\text { Menjelaskan konsep } \\
\text { energi dan daya } \\
\text { listrik }\end{array}$ & 3 & 27 & 37 & 88 & 51 & 0.75 & Tinggi & 0.20 & Rendah \\
\hline 10. & $\begin{array}{l}\text { Menghitung energi } \\
\text { dan daya listrik }\end{array}$ & 3 & 26 & 15 & 95 & $\begin{array}{l}9 \\
6\end{array}$ & 0.84 & Tinggi & 0.87 & Tinggi \\
\hline 11. & $\begin{array}{l}\text { Menjelaskan upaya- } \\
\text { upaya penghematan } \\
\text { listrik }\end{array}$ & 2 & 63 & 50 & 70 & 67 & 0.78 & Tinggi & 0.77 & Tinggi \\
\hline
\end{tabular}

Tabel 3 menunjukkan terlihat bahwa terdapat perbedaan peningkatan indikator hasil belajar peserta didik pada kelas eksperimen dan kelas kontrol. Peningkatan indikator yang paling tinggi pada kelas eksperimen adalah pada indikator 5 mengenai penulisan konsep hukum ohm dengan $\mathrm{N}$ Gain 0,93 dalam kategori tinggi dan peningkatan indikator yang paling rendah pada kelas eksperimen adalah indikator 4 mengenai perhitungan besar hambatan total pada rangkaian listrik seri, paralel dan rangkaian campuran dengan $\mathrm{N}$-Gain 0,35 dalam kategori tinggi. Sedangkan pada kelas kontrol peningkatan indikator yang paling tinggi pada kelas kontrol yaitu indikator 10 menghitung energi dan daya listrik dengan $\mathrm{N}$-Gain 0,87 dalam kategori tinggi. Peningkatan indikator yang paling rendah pada kelas kontrol adalah indikator 6 tentang mendeskripsikan bunyi hukum I Kirchhoff dengan N-Gain 0,18 dalam kategori rendah.

\section{b. Analisis Statistik Inferensial.}

Hasil analisis statistik inferensial disajikan untuk pengujian hipotesis, dalam uji-t dengan taraf signifikansi $a=0,05$. Syarat yang harus dipenuhi untuk pengujian hipotesis adalah data yang diperoleh harus terdistribusi normal dan mempunyai variansi yang homogen. Oleh karena itu terlebih dahulu dilakukan uji normalitas dan uji homogenitas.

Kelas eksperimen, dari hasil perhitungan tabel diperoleh nilai $X^{2}$ hitung sebesar 10.4277 sedangkan nilai $X^{2}$ tabel pada taraf signifikan $\alpha=0,05$ dan derajat kebebasan $(\mathrm{dk})=\mathrm{n}-1$ diperoleh $X^{2}$ tabel $=11,07048$. Berdasarkan hasil analisis data tersebut dinyatakan bahwa $X^{2}$ hitung $<X^{2}$ tabel yaitu $10.4277<11,07048$ maka dapat disimpulkan data pada kelas eksperimen terdistribusi normal. Kelas kontrol, dari hasil perhitungan tabel diperoleh nilai $X^{2}$ hitung sebesar 7.7224 sedangkan nilai $X^{2}$ tabel pada taraf signifikan $a=0,05$ dan derajat kebebasan $(\mathrm{dk})=\mathrm{n}-1$ diperoleh $X^{2}{ }_{\text {tabel }}=11,07048$. Berdasarkan hasil analisis data tersebut dinyatakan bahwa $X^{2}{ }_{\text {hitung }}<X^{2}$ tabel yaitu 7.7224 $<11,0704$ maka dapat disimpulkan data pada kelas kontrol terdistribusi normal.

Setelah kedua sampel dinyatakan terdistribusi normal, maka dilakukan uji homogenitas menggunakan skor $\mathrm{N}$-Gain. Berdasarkan hasil perhitungan untuk data dari kelas eksperimen dan kontrol diperoleh $F_{\text {hitung }}=2,51$ pada taraf nyata $a=0,05$, maka $F_{\text {tabel }}=3,13$. Oleh karena itu $F_{\text {hitung }}=2,51$ $<\mathrm{F}_{\text {tabel }}=3,13$, dengan demikian bahwa varians data kedua kelompok tersebut dinyatakan sama (homogen). 
Berdasarkan pengujian hipotesis dengan menggunakan uji-t hasil analisis diperoleh $t_{\text {hitung }}=$ $6,33>t_{\text {tabel }}=3,45$. Hal ini berarti $H_{0}$ ditolak dan $H_{1}$ diterima. Sehingga dapat disimpulkan bahwa media simulasi PhET berpengaruh positif terhadap peningkatan hasil belajar peserta didik kelas IX SMP Negeri 13 Makassar pada materi pokok listrik dinamis.

Setelah itu dilakukan penaksiran rata-rata populasi yang dapat mengeneralisasikan hasil penelitian untuk populasi. Sehingga hasil penelitian ini dapat dijadikan sebagai parameter populasi. Taksiran rata-rata hasil belajar pada populasi didapatkan $0,68 \leq \mu \leq 0,76$

\section{Pembahasan}

Pada penelitian ini, hasil belajar yang diukur hanya pada aspek kognitif. Hasil belajar kognitif kelas eksperimen dilihat dari skor rata-rata N-gain lebih tinggi dibandingkan kelas kontrol dimana rata-rata skor $\mathrm{N}$-gain di kelas eksperimen yaitu 0.72 berada pada kategori tinggi sedangkan kelas kontrol yaitu 0,53 berada pada kategori sedang. Perbedaan rata-rata skor N-gain pada kedua kelompok menunjukkan bahwa penggunaan media simulasi PhET lebih efektif dalam meningkatkan hasil belajar peserta didik, artinya peserta didik yang mengikuti pembelajaran dengan menggunakan media simulasi PhET memiliki kemampuan yang lebih tinggi dibandingkan dengan tanpa penggunaan media simulasi PhET. Hal ini disebabkan karena pada media simulasi PhET peserta didik dapat melakukan simulasi percobaan terlebih dahulu sehingga pada saat melakukan percobaan peserta didik sudah mengerti apa yang akan dilakukan. Selain itu, peserta didik juga lebih mudah memahami konsep dari materi listrik dinamis karena bisa mengamati bagaimana suatu rangkaian listrik bisa menyalakan lampu. Selain itu, di kelas kontrol yang menggunakan media gambar yang hanya menekankan presepsi indra mata selain itu, sehingga peserta didik juga masih bertanya-tanya bagaimana suatu rangkaian listrik bisa menyalakan bohlam. Media gambar yang hanya diam tentu membuat konsep listrik dinamis bersifat abstrak.

Aplikasi ini memiliki animasi interaktif dikembangkan seperti permainan yang dapat memungkinkan siswa bereksplorasi. Selain itu PhET juga menekankan hubungan antara fenomena kehidupan nyata dan ilmu yang mendasarinya yang diungkapkan dalam model visual dan konseptual dengan pendekatan berbasis penelitian yang mendukung keterlibatan siswa sehingga membantu mereka untuk memahami konsep fisika (Wieman dkk, 2009).

Hasil analisis tiap indikator hasil belajar pada dua kelas yaitu kelas eksperimen dan kelas kontrol dimana terdapat 11 indikator hasil belajar. Pada indikator 3 yaitu menjelaskan karakteristik rangkaian listrik seri dan paralel, kelas eksperimen berada pada kategori tinggi sedangkan kelas kontrol berada pada kategori sedang. Perbedaan tersebut disebabkan karena di kelas eksperimen peserta didik membuat rangkaian seri dan paralel melalui aplikasi media simulasi PhET sehingga peserta didik lebih mudah memahami perbedaan antara rangkaian seri dan paralel sedangkan di kelas kontrol peserta didik hanya melihat gambar rangkaian seri dan rangkaian paralel.

Memperkuat hasil analisis deskriptif, maka dilakukan analisis statistik inferensial dimana diambil dari data statistik deskriptif $\mathrm{N}$-gain untuk membuktikan hipotesis yang diajukan dengan menggunakan satistik uji t. Sebelum digunakan uji t, terlebih dahulu di lakukan uji normalitas dan homogenitas. Uji normalitas data digunakan untuk menguji kenormalan data skor sedangkan uji homogenitas digunakan untuk menguji data apakah homogen atau tidak. Data dapat dikatakan Homogen apabila $x^{2}$ hitung $<x^{2}$ tabel dan data dikatakan homogen apabila $\mathrm{F}_{\text {hitung }}<\mathrm{F}_{\text {tabel }}$. Berdasarkan uji normalitas dan homogenitas, maka seluruh kelompok data telah memenuhi syarat.

Adapun hasil pengujian normalitas pada hasil belajar kelas eksperimen yang diajar menggunakan media animasi diperoleh yaitu $\chi_{\text {hitung }}^{2}<\chi_{\text {tabel }}^{2}$ yaitu 10,4277 $<11,07048$ yang berarti nilai hasil belajar peserta didik berasal dari populasi yang terdistribusi normal. Kemudian pada kelas kontrol yang diajar tanpa menggunakan media animasi diperoleh $\chi^{2}{ }_{\text {hitung }}<\chi^{2}{ }_{\text {tabel }}$ yaitu $7,7224<11,07048$ yang berarti nilai hasil belajar peserta didik juga berasal dari populasi yang 
terdistribusi normal. Setelah perolehan data yang telah terdistribusi normal selanjutnya dilakukan uji homogenitas dan berdasarkan analisis yang diperoleh yaitu $F_{\text {hitung }}<F_{\text {tabel }}$ yaitu $2,51<3,13$. Hal ini menunjukkan bahwa varians data kedua kelompok dalam penelitian ini termasuk homogen sehingga pengujian hipotesis dapat dilakukan dengan menggunakan uji-t. Selanjutnya dilakukan analisis uji-t hasil belajar diperoleh thitung $(6,33)>t_{\text {tabel }}(3,45)$, berdasarkan kriteria pengujian hipotesis statistik berarti $\mathrm{H}_{0}$ ditolak dan $\mathrm{H}_{1}$ diterima. Dengan demikian media simulasi PhET berpengaruh positif terhadap peningkatan hasil belajar peserta didik kelas IX SMPN 13 Makassar pada materi listrik dinamis.

Agar hasil penelitian yang diperoleh dapat digunakan untuk digeneralisasikan ke populasi maka dilakukan analisis lanjutan yaitu dengan analisis inferensial taksiran rata-rata populasi. Hasil analisis taksiran rata-rata populasi untuk hasil belajar $0,68 \leq \mu \leq 0,76$ artinya bila kita mengambil secara acak sampel dari populasi kelas IX di SMPN 13 Makassar, maka skor rerata motivasi belajar yang didapatkan berada pada kisaran tersebut dengan koefisien kepercayaan 0,95 atau 95\%.

Peningkatan hasil belajar peserta didik pada kelas eksperimen selain karena penggunaan media simulasi PhET dengan model discovery learning juga dikarenakan partisipasi aktif peserta didik dalam proses belajar mengajar terutama pada saat pengerjaan LKPD karena peserta didik di kelas eksperimen sudah paham prosedur kerja yang akan dilakukan karena telah melakaukan simulasi percobaan. Hasilnya dapat dilihat pada perbedaan skor LKPD kelas kontrol dan kelas eksperimen, dengan skor rata-rata kelas eksperimen setiap pertemuan yaitu 82,83., 88,83., 82,33., 82,16., 65,83., dan 70,66 sedangkan skor rata-rata kelas kontrol setiap pertemuan yaitu 61,50., 83,16., 57,50., 59,16., 78, dan 51,83. Pada pertemuan kelima rata-rata skor kelas eksperimen lebih rendah dibandingkan rata-rata skor kelas kontrol pada pertemuan kelima hal ini disebabkan karena pada kelas eksperimen beberapa kelompok tidak membawa bahan praktikum sehingga percobaan tidak berjalan dengan baik.

Penelitian ini menunjukkan bahwa penggunaan media pembelajaran dalam proses pembelajaran dapat meningkatkan hasil belajar peserta didik. Hasil penelitian ini selaras dengan penelitian yang terdahulu yang dilakukan oleh Lubis (2015); Magfirah (2018); Nurhayati (2017); dan Saenab (2018). Selain itu Wibowo (2018) juga menemukan bahwa Media PhET dapat memberi pengaruh terhadap pengusaan konsep. Penelitian yang dilakukan oleh Sari, Tjandrakirana, \& Kuntjoro, (2018) juga menunjukkan bahwa penerapan media simulasi PhET mampu meningkatkan keterampilan proses dan pengetahuan siswa SMP pada materi cahaya dan optik.

\section{KESIMPULAN}

Berdasarkan hasil analisis data dan pembahasan maka dapat disimpulkan bahwa:

1. Peningkatan hasil belajar peserta didik kelas IX SMP Negeri 13 Makassar yang diajar menggunakan media simulasi PhET pada materi listrik dinamis dengan rata-rata N-gain 0,72 berada pada kategori tinggi.

2. Peningkatan hasil belajar yang tidak diajar menggunakan media simulasi PhET dengan ratarata N-gain 0,53 berada pada kategori sedang.

3. Terdapat pengaruh media simulasi PhET terhadap peningkatan hasil belajar peserta didik kelas IX SMPN 13 Makassar.

\section{DAFTAR PUSTAKA}

Lubis, F. M., \& Harahap, M. B. (2015). Efek Model Pembelajaran Kooperatif Tipe NHT (Numbered Heads Together) Menggunakan Media Simulasi PhET dan Aktivitas Terhadap Hasil Belajar Siswa. Jurnal Pendidikan Fisika, 39-40. 
Magfirah, A., Mamin, R., \& Mun'im, A. (2018). Pengaruh Media Gambar pada Model Pembelajaran Langsung terhadap Hasil Belajar Peserta Didik Kelas VIII MTs Muhammadiyah Cabang Mamajang (Studi Pada Materi Pokok Sistem Pencernaan). Jurnal IPA Terpadu, Volume 2 Nomor 1.

Nurhayati. (2017). Peningkatan Hasil Belajar Biologi melalui Penggunaan Media Kartu Bergambar Siswa Kelas VIII-B SMP Negeri 3 Sengkang Kabupaten Wajo. Jurnal IPA Terpadu, Volume 1 Nomor 1.

Saenab, S., Ramlawati, \& Suryani, I. (2018). Pengaruh Media Video dengan Pendekatan Kontekstual terhadap Hasil Belajar IPA Kelas VII MTs Negeri Gantarang Kabupaten Bantaeng (Pada Materi Pokok Pencemaran Lingkungan). Jurnal IPA Terpadu, Volume 1 Nomor 2.

Sari, P. D., Tjandrakirana, \& Kuntjoro, S. (2018). Applying Science Learning Phet Simulation To Improve Process Skill And Knowledge Aspect Of Junior High School Student. Jurnal Penelitian Pendidikan Sains, 1498-1499.

Sumargo, E., Yuanita, \& Lenny. (2014). Penerapan Media Laboratorium Virtual (Phet) pada Materi Laju Reaksi dengan Model Pengajaran Langsung. Volume 3 Nomor 1.

Wartono. (2003). Strategi Belajar Mengajar. Malang: Jurusan Pendidikan Fisika FPMIPA Universitas Negeri Malang.

Wibowo, B. (2018). Pengaruh Pembelajaran Ipa Menggunakan Phet Interactive Simulation Terhadap Motivasi Belajar Dan Penguasaan Konsep Sains Siswa. E-Journal Pendidikan, 372.

Wieman, C., Adams, W., \& Perkins, K. (2009). PhET: Simulations That Enhance Learning. Columbia: Departement of Physics University of Colorado.

Received, 13 Januari 2021

Accepted, 29 Maret 2021

\section{A Husnul Haerana}

Mahasiswa Program Studi Pendidikan IPA FMIPA UNM, aktif melakukan penelitian pada bidang Pendidikan IPA, dapat dihubungi melalui email: Ranahaerana97@gmail.com

\section{Ramlawati}

Dosen Program Studi Pendidikan IPA FMIPA UNM, aktif melakukan penelitian pada bidang Pendidikan IPA, dapat dihubungi melalui email: ramlawati@unm.ac.id.

\section{Sitti Rahma Yunus}

Dosen Program Studi Pendidikan IPA FMIPA UNM, aktif melakukan penelitian pada bidang Pendidikan IPA, dapat dihubungi melalui email: sitti.rahma.yunus@unm.ac.id 